\title{
Social Media as Amedium of Crisis Communication Amongst University Campuses in Kisii County
}

\author{
Everlyn Chelang'at Kimibei \\ Kisii University, School of Information Science and Technology, Department of Communication, Media and \\ Information Sciences. P.O. Box 408, Kisii \\ Jonai Wabwire \\ Kisii University, School of Information Science and Technology, Department of Communication, Media and \\ Information Sciences. P.O. Box 408, Kisii
}

\begin{abstract}
Social media gives the ability to communicate quickly and effectively, revolutionizing the manner in which people communicate and gather information about stories and topics that are of interest to them. With the right tools in place, social media can play an important role in crisis communication. The use of social media in crisis communication has become common in the current digital age. The manifestation of social media usage is in the rapid growth and popularity of such social media platforms such as facebook, bandoo, flicker, twitter and whatsApp. As such this paper examined the applications of social media platforms in crisis communication in university management. The analysis targeted employees from different university campuses in Kisii County. The study sampled 108 employees of university campuses in Kisii County. Quantitative data that was collected were analyzed using descriptive statistics while qualitative data was examined and reported basing on various themes. Data indicated that various social media platforms are in use by the university campuses in their crisis communication. Whatsapp was noted to be the most used social media by the university campuses in Kisii County. As a tool for mobile devices, WhatsApp has several capabilities such as portability, ability to share several message formats such as graphics and geographical location, ability to send voice notes and ability to broadcast one message to many recipients. This makes it attractive to the majority of the users.
\end{abstract}

Keywords:Crisis Communication, social media, digital age, telecommunication firms, crisis; crisis communication; whatsApp.

DOI: $10.7176 / \mathrm{NMMC} / 96-05$

Publication date:May $31^{\text {st }} 2021$

\subsection{Introduction}

Social media has become a crucial means of communication. This is evidenced by the growth and popularity in the usage of Twitter, Facebook, YouTube and LinkedIn (Pondres, 2011). The 'big three' services, namely, Facebook, Twitter and Youtube have grown tremendously in the last couple of years; with Facebook, for example, started in 2004, growing to 845 million active users worldwide by 2012. Similarly, Twitter has grown increasingly in five years since it was created in 2006 to over 300 million users and with the establishment of YouTube in 2005 it has become easier to distribute video content (Shirky, 2011). One of the underlying factors of this increase in popularity is because social media make it possible for large numbers of people to easily and inexpensively communicate. Also, the user-friendliness and accessibility of the social media have increased its popularity, because the social media make it possible for everyone to share information (Safranek, 2012). Demographically, the use of social media involves many actors, like regular citizens, activists, nongovernmental organizations, telecommunication firms, software providers, as well as governments (Shirky, 2011). Many organizations are often embroiled in crises, cover-ups, security breaches, and transgressions of ethical behavior; these are the stuff from which corporate crises emanate

Fronting a positive image and maintaining a good reputation is arguably an important part of long term planning in any sound contemporary organization. By managing and handling a crisis effectively and efficiently, the positive perceptions of stakeholders and the public are vital to an organization. An important strategy in managing a crisis is the use of various types of social media in order to communicate with the public to convey current information about an issue or crisis in the fastest and easiest way while building and maintaining the trust of and relationships with the stakeholders. Currently, technological advances are transforming and disseminating information to the affected communities in the fastest and easiest ways (Veil, Buehner \& Palenchar, 2011). These methods include micro blogging, blogs, social networking sites (Facebook, Twitter, LinkedIn, Instagram, YouTube), video sharing, content driven communities as well as professional networks (Walaski, 2013). During a crisis, it is important for an organization to communicate their response regarding the crisis with the organization's stakeholders (Modeus, Paulsson \& Olsson, 2012). The effective and efficient communication of the crisis with the stakeholders will lessen negative perceptions and threats to the organization's reputation. The organization or individual who will be crisis communicators should comprehend, construct and deliver messages 
to the directly or indirectly affected stakeholders and crisis communicators and should also prepare to receive and respond to feedback from these audiences (Zaremba, 2010).

Inadequate research in identifying the importance of social media as the most effective medium during a crisis has resulted in many companies deciding not to employ this crisis strategy (Goldfine, 2011). Therefore, this study attempts to examine the importance of social media as a communication platform during a crisis and how various forms of social media play different roles in disseminating information to different audiences during a crisis. In this study, key concepts such as crisis, crisis management, crisis communication and social media will have been defined and explored with recent insight and overviews from academic practices in order to clarify the importance of why an organization should consider social media as a crisis communication platform. Finally, this study demonstrates the best practice use of social media as a platform in a risk and crisis situation.

A crisis is unexpected and introduces an intense threat to the organization. It is not simply a negative event, but one that is unique, or non-routine in the sense that it cannot be managed by normal procedures, but, rather, requires unique and extreme measures. Crises also produce uncertainty, in both causes and effects. A crisis is "a specific, unexpected, non-routine event or series of events that create high levels of uncertainty and threaten or are perceived to threaten an organization's high priority". As the number of organizational crises increases, crisis communication and crisis management are essential in the practice of public relations. Just as organizations vary in type and size, the crises they face vary in nature. Social media have changed the way practitioners respond and prepare in crises (Pondres, 2011). In addition, the increasing influence of the social media is illustrated by recent developments where the social media also has had influence on governments. The revolutionary events in the Middle-East in the spring of 2011, that is, the so-called Arabic Spring can be seen as a good example of the emerging role of social media in political and regime change (Safranek, 2012). But what do these recent developments imply for public policy makers? It means that there is a situation in which the social media cannot be ignored any longer by the authorities. It is therefore important to determine whether this is also the case for authorities in crisis communication.

Studies such as Bos, van der Veen \& Turk ( 2010) have already shown that the use of social media in crisis communication by authorities can be effective. Crises have the potential to bring down a university or any other organization. How an organization plans for and responds to a crisis directly correlates to how or if they will survive the crisis. Managers must put together a team; develop a plan for each potential crisis that could impact the organization. Social media is a tool that allows interactivity between the manager and the organization. The role social media can play in crisis communication has barely been studied. What role and what impact social media can have on a crisis is still uncertain. This paper gives a new insight in the role of social media in crisis communication where a democratic orientation is prominently in play. The focus will be how social media can be useful in achieving the objectives of crisis communication in providing sufficient information and limitation of harm, and why at the same time social media is important in crisis communication from a democratic point of view.

\subsection{Literature Review}

Kaplan \& Haelein (2010) notes that while the term "social media" is imprecise, it can be applied to a wide range of web applications, ranging from social networking sites to blogs, to collaborative content sites, virtual game worlds and virtual social worlds. The way social media allows universities to interact with customers marks a clear delineation between social media and more traditional forms of crisis communication. Key to understanding this difference is the recognition that social media is a two-way information flow, versus the oneway information flow that is more traditional with media like television, radio or print. Social media allows officers to use media outlets on the Internet as a means of communicating with others, defining social media at least a two-way information flow. Officers use social media to interact not just with each other, but with the broader world around them. An example of this could be in the use of social media to champion causes or even organize people for in person meetings, protests or even marketing events (Valenzuela, Park \& Kee, 2009). Organizations have had to change their relationship with officers entirely as the result of the proliferation of social media. They use social media to disseminate information in a one-way flow, but must also engage in twoway flow of information. Social media avail the opportunity to gather more information from officers, something that can help with targeting efforts. Indeed, social media's hands-on nature demands that strong targeting is utilized so that the company continues to derive value for its budget. One of the key challenges for marketers has been learning how to integrate social media with the offline world (Smith \& Zook, 2011).

\subsection{Crisis}

Eid \& Fyfe, (2009) defined a crisis as "a situation generally distinguished from routine situations by a sense of urgency and a concern that the problem will become worse in the absence of action". Crises inevitably endanger the reputation of a university and crisis communication then becomes the central focus of a corporation (Muralidharan, Dillistone \& Shin, 2011). Crisis management in a university set up can be defined as the several 
ways a university organization employs to prevent or reduce the impact of the crisis (Coombs, 2012, p. 5). During a crisis, it is important for a university organization to communicate their response regarding the crisis with the organization's stakeholders.

\subsection{The role of social media in crisis communication}

In a previous study, the new forms of social media such as Facebook, Twitter and so on were recognized as an organization's opportunity to lessen the impact in times of a crisis (Wendling, Radisch \& Jacobzone, 2013). It is reasonable to note that previously, radio, television, newspapers and other traditional media sources were used to transmit valuable information but nowadays social media such as Facebook and Twitter are tools which can assist an organization to disseminate and share information with as many people as possible while receiving feedback and responses from the public instantly. This means that an organization employs the technology of social media as part of the communication process to the world. The continuous use of social media as a tool seems likely for the foreseeable future (Anderson \& Rainie, 2010).

\subsection{Organization and social media during a crisis}

Organizations that are sensitive to changes and usage of technology and the internet constantly use Twitter, blogs, mobile phones and other social network tools to spread the news of the crisis (Pang, Hassan \& Chong, 2014). On the other hand, Schultz, Utz and Goritz (2011) identify that blogs are effective tools for repairing an organization's image and reputation while preventing a boycott in crisis situations. In order to do so, Jin and Liu (2010) have proposed the blog-mediated crisis communication model in order to help an organization or crisis communicators to monitor the blogosphere and respond appropriately to influential bloggers running damaging communication during a crisis. This aims to avoid inaccurate information from the public especially bloggers spreading bad news, which can cause the tarnishing of an organization's reputation and image. Liu (2010) stated that during a crisis period, people seek immediate and in-depth crisis information in contrast with Stephens \& Malone (2009) who claim that people usually tend to rely on word of mouth by using social media instead of searching for information directly from a corporate website or blogs. They argue that this is because blogs just tend to allow people to engage in knowledge sharing, reflection and the exchange of views, which normally encourages the public for the purpose of readership and builds trust after a crisis (Valentini \& Romenti, 2011). Thus, during a crisis, people tend to seek and use various types of social media to gather as much additional information as possible regarding the risks and responsibilities of the crisis (Valentini \& Romenti, 2011). In addition, Facebook has more than one billion users worldwide (Hysenlika, 2012), which represent the most popular social media site. Hysenlika (2012) claimed that Facebook allows communicators to deliver messages based on their needs quickly and effectively during a crisis period. This can be proved by Energex (n.d), an organization that successfully communicated and shared information with the public by using social media tools in Australia. Energex provided and offered a social media networking page on Facebook for the purpose of sharing information including power interruptions, safety and storm information, energy saving tips, sponsorship opportunities and community initiatives, invitations to provide feedback on specific issues as well as informing the public of new content on the digital channels (Energex, n.d.). Thus, social media can be an effective communication platform not only to be used to reduce the crisis impact but also as a tool to share knowledge and the management of a crisis by an organization (Yates \& Paquette, 2011).

\subsection{Social media platforms.}

Social media platforms include blogs, virtual communities, social networking, collaborative tagging and media file sharing sites such as YouTube and Flickr (Xiang and Gretzel, 2010). Social media's capacity is designed to enable people to connect, share and collaborate, which has resulted in its increasing use in personal, business and educational domains (White, King \& Tsang, 2011). Walaski (2013) supports the study stating that social media platforms and methods include micro blogging, blogs, social networking sites which are Facebook, Twitter, LinkedIn, Instagram and also YouTube. Nowadays, a variety of social media platforms enable organizations to provide information about a crisis effectively because they represent the new way of communicating: digital, computerized and communication technology that allows networking in the fastest and most efficient ways to different audiences simultaneously (White, 2012). Social media has the potential to influence the manner in which individuals think, behave and respond to information and situations in general in times of crises (Paul, as cited by Schroeder \& Pennington-Gray, 2014). The role of social media as a communication platform during a crisis is important and unavoidable (Schroeder et al., 2013). Social media can be useful to improve preparedness and responses, reduce the cost of disasters, improve transparency of decisions and also increase the potential acceptance of outcomes (Wendling et al., 2013). Indeed, social media can be one of the primary crisis communication strategies during a disaster (Cho \& Park, 2013). A recent study by Axel (2014) shows how the different types of social media are important in ensuring effective crisis communication in their capacity to provide the right information at the right time to the right people. 


\subsection{Methodology}

A descriptive survey design was applied in this inquiry to establish the impact of social media on crisis communication amongst universities in Kisii County. The design is devoted to the gathering of information about prevailing conditions or situations for the purpose of description, interpretation and inference generation. It is concerned not only with the characteristics of individuals but with the characteristics of the whole sample therein. It provides information useful to the solutions of local issues (Aggarwal, 2008). As such the population of the study consisted of employees from different university campuses in operation in Kisii County as indicated in the table 1.

\section{Table 1: Target Population}

\begin{tabular}{lccc}
\hline Institution & $\begin{array}{c}\text { Program } \\
\text { coordinators }\end{array}$ & $\begin{array}{c}\text { Heads of } \\
\text { department }\end{array}$ & Staff \\
\hline African Nazarene University & 02 & 02 & 20 \\
Bugema University & 02 & 03 & 12 \\
Gretsa University & 01 & 01 & 12 \\
Jomo Kenyatta University & 02 & 04 & 33 \\
JOOUST University & 01 & 02 & 15 \\
Maasai Mara University & 01 & 02 & 09 \\
Moi University & 01 & 02 & 27 \\
Mount Kenya University & 02 & 05 & 09 \\
St. Paul's University & 02 & 01 & 12 \\
University of Eldoret & 02 & 01 & 32 \\
University of Nairobi & 02 & 03 & $\mathbf{1 9 2}$ \\
\hline Total & $\mathbf{1 8}$ & $\mathbf{2 6}$ & \\
\hline
\end{tabular}

County Education Office (2015)

Kerlinger (1983) says that a sample size of $30 \%$ of the target population is large enough so long as it allows for reliable data analysis. This was used to calculate the sample sizes.

$$
n=N x \frac{30}{100}
$$

Where $\mathrm{n}$ is the sample size, $\mathrm{N}$ is the population size, and $30 \%$ is the estimate:

$$
\begin{gathered}
n=192 \times \frac{30}{100} \\
n=64
\end{gathered}
$$

Therefore, a total of 64 staff took part in the research.

Purposive sampling was used to determine the program coordinators and heads of departments. The study used 18 program coordinators and 26 heads of departments. Both stratified and simple random sampling techniques were used for the study in determining respondents to be sampled. Purposive sampling was used since the officers have knowledge of the population under study. It is useful for situations where one needs reach a target population quickly and where sampling for proportionality is not a main concern (Orodho and Kombo, 2002).

Table 2: Distribution of study population and the sample size

\begin{tabular}{lcccccc}
\hline Institution & \multicolumn{2}{c}{$\begin{array}{c}\text { Program } \\
\text { Coordinators }\end{array}$} & \multicolumn{2}{c}{ Heads of department } & \multicolumn{2}{c}{ Staff } \\
& $\begin{array}{c}\text { Study } \\
\text { population }\end{array}$ & $\begin{array}{c}\text { Sample } \\
\text { Size }\end{array}$ & $\begin{array}{c}\text { Study } \\
\text { population }\end{array}$ & $\begin{array}{c}\text { Sample } \\
\text { size }\end{array}$ & $\begin{array}{c}\text { Study } \\
\text { population }\end{array}$ & $\begin{array}{c}\text { Sample } \\
\text { size }\end{array}$ \\
\hline African Nazarene University & 02 & 02 & 02 & 02 & 20 & 7 \\
Bugema University & 02 & 02 & 03 & 03 & 12 & 4 \\
Gretsa University & 01 & 01 & 01 & 01 & 12 & 4 \\
Jomo Kenyatta University & 02 & 02 & 04 & 04 & 33 & 11 \\
JOOUST University & 01 & 01 & 02 & 02 & 15 & 5 \\
Maasai Mara University & 01 & 01 & 02 & 02 & 09 & 3 \\
Moi University & 01 & 01 & 02 & 02 & 11 & 4 \\
Mount Kenya University & 02 & 02 & 05 & 05 & 27 & 9 \\
St. Paul's University & 02 & 02 & 01 & 01 & 09 & 3 \\
University of Eldoret & 02 & 02 & 01 & 01 & 12 & 4 \\
University of Nairobi & 02 & 02 & 03 & 03 & 32 & 11 \\
\hline Total & $\mathbf{1 8}$ & $\mathbf{1 8}$ & $\mathbf{2 6}$ & $\mathbf{2 6}$ & $\mathbf{1 9 2}$ & 64 \\
\hline
\end{tabular}

The research study used a questionnaire and an interview schedule, since they offered a variety of possible 
responses to collect the data from the students. Both qualitative and quantitative data was collected and analyzed by use of Statistical Package for Social Sciences (SPSS). Qualitative data was read and categorized into distinct themes while quantitative data was analyzed by use of descriptive statistics and multiple correlations. The findings were presented in the form of frequency tables, percentages and reports.

\subsection{Results}

The study sought to find out the application of social media in crisis communication especially in the present digitally connected world. The table below shows the rate of social media usage in university campuses in kisii County.

Table 3: Usage of Social Media

\begin{tabular}{lcc}
\hline Item & Frequency & \% \\
\hline Yes & 95 & $87.96 \%$ \\
No & 13 & $12.04 \%$ \\
\hline Total & $\mathbf{1 0 8}$ & $\mathbf{1 0 0}$
\end{tabular}

Source: Field Data (2016)

Looking at the table above, it is apparent that $87.96 \%$ of the respondents used social media actively. Only $12.04 \%$ of the respondents did not use social media. It can therefore be concluded that usage of social media is evident in Universities in Kisii County and Kenya at large. This demonstrates the current trend of universities adopting and applying various social media platforms in their running of daily affairs including remedying crisis situations.

In a previous study, the new forms of social media such as Facebook, Twitter were recognized as organization's opportunity to lessen the impact in times of a crisis (Wendling, Radisch \& Jacobzone, 2013). Previously, traditional radio, television, newspapers and other media sources were used to transmit valuable information but nowadays social media such as Facebook and Twitter are tools which can assist an organization to disseminate and share information with as many people as possible while receiving feedback and responses from the public. This implies that current organizations such as universities employ the technology of social media as part of the communication process to the world. It was also apparent that social is not only used in crisis communication but also useful in other spheres of communication. The continuous use of social media as a tool seems likely for the foreseeable future (Anderson \& Rainie, 2010).

\section{Type of Social Media Used by Respondents}

In the surveys carried out, numerous social media platforms were used by various university campuses within Kisii County. The table below summarizes data on various types of social media commonly in use among the various university students and managers:

Table 4: Type of social media used

\begin{tabular}{lcc}
\hline Item & Frequency & \% \\
\hline Twitter & 77 & $71.30 \%$ \\
Facebook & 85 & $78.70 \%$ \\
Manual systems & 8 & $7.41 \%$ \\
YouTube & 58 & $53.70 \%$ \\
LinkedIn & 12 & $11.11 \%$ \\
Skype & 23 & $21.30 \%$ \\
Whatsapp & 99 & $91.67 \%$ \\
\hline Total & $\mathbf{1 0 8}$ & $\mathbf{1 0 0}$ \\
\hline
\end{tabular}

Source: Field Data (2016)

From the collected data above What Sapp leads with $91.67 \%$ in usage as a type of social media, $78.70 \%$ used Facebook as a as a type of social media, about $71.30 \%$ of the respondents used Twitter as a type of social media. $53.70 \%$ of the respondents used YouTube as a type of social media, $21.30 \%$ used Skype as a as a type of social media, about $11.11 \%$ of the respondents used LinkedIn as a type of social media. Only $7.41 \%$ of the respondents used manual systems. It is clear that the majority of the respondents used Whatsapp as a form of social media while manual systems was the least form adopted social media platform. One of these platforms is WhatsApp, whose adoption rate has enormously grown from its inception in 2009, with the current number of users surpassing 1 billion in over 180 countries (WhatsApp, 2016; Wariara, 2017). In Kenya, 49\% of mobile users have WhatsAppon their phone and understand its applications in communication (Adika, 2014). Its use has penetrated even into institutions and organizations. Therefore, with the current growth rate, the need to understand the usage and the satisfaction that users are getting from it cannot be overlooked.

The use of WhatsApp as a communication platform has proliferated globally and in Kenya in the last 3 years. Forty nine percent of mobile users in Kenya were using the application by 2014 (Adika, 2014). With the significant growth of smartphones, more so in African countries, there has been an influx in the usage of the 
mobile messaging platform, WhatsApp. Though the medium has numerous beneficial uses, WhatsApp has been cited to have privacy issues. For example, Church and de Oliveira (2013) observe that contacts are able to see if messages are delivered and read as well as time of last access. Although users have the option of privacy settings, the voluminous incoming messages and the extent of interruption they cause often force them to put the phone on silent mode (Church \& de Oliveira, 2013), which may hinder effective communication within the network. In addition, the platform requires one to have internet so as to use it and one can only chat with friends who have smartphones and WhatsApp installed (Dekhne, 2016). Despite the limitations of WhatsApp, it continues to appeal to the users and its adoption levels continues to grow with time (WhatsApp, 2016).

A university should have policies that govern both internal and external communication as it dictates how members should communicate and the channels that they should use. "With no formal policy, the lack of explicit rules creates risk" (Efimova \& Grudin, 2007, p. 5). From this, the question arises as to why WhatsApp, as a social media platform, is used within universities technology division yet it is not part of the official communication channels that the universities have laid down and also in an environment where no policy governs its usage (Safaricom, 2006). In addition, the usage of WhatsApp continues to grow even with the limitation that the medium has such as privacy and lack of control as to who has visibility of the messages that are shared using the platform.

On the other hand, Facebook and twitter had a reasonable percentage of application in communication services in the university set up. A final element of this study involved establishing the individual university related Facebook posts and tweets that received the most 'shares' by the public and determining at which flood stage they were shared. Public interaction on Facebook exceeded that of Twitter, in other words the shares of Facebook posts, exceeded the twitter retweets as indicated in the percentages on table 4. Social media users in the university set up were most likely to redistribute university related information generated by crises communication sections. Public interaction with university related information was most likely to occur at the response stage, as evidenced among the most frequently shared Facebook posts and tweets. The key topics within the most frequently shared or retweeted posts were: education program information, vacancies, calls for academic papers,

\section{Crisis Plan}

The study sought to find out crisis plans in the universities as recorded in the table 4.9 below. Table 5: Crisis Plan

\begin{tabular}{lcc}
\hline Item & Frequency & \% \\
\hline Yes & 83 & $76.85 \%$ \\
No & 25 & $23.15 \%$ \\
\hline Total & $\mathbf{1 0 8}$ & $\mathbf{1 0 0}$ \\
\hline
\end{tabular}

Source: Field Data (2016)

In relation to table 5 , it was established that $76.85 \%$ of the respondents were aware that the university had a crisis plan. Only $23.15 \%$ of the respondents did not have any information about the university crisis plan. It can therefore be concluded that universities in Kisii County have crisis plans. Respondents were asked to rate the best practices that integrate social media into the crisis communications using the scale below; $5=$ Always, $4=$ Often, 3 = Seldom, 2 = Rarely and $1=$ Never

Failure to have a crisis plan is very dangerous for any sound organization. As a necessity, universities are viewing crisis planning with increased interest. Understanding the importance of crisis planning is different from developing effective plans, particularly when management may have to sell the need for crisis planning to university organizational cultures that previously looked upon the effort as a waste of time and money. According to Michelle (2011), attempting to plan for all the potential crises that could conceivably strike a university can be time-consuming, tiresome, and difficult. As such, even universities that choose to plan for crises may find their plans shallow, overly-simplistic, or ineffective when crises occur and plans are put to the test. To effectively tackle adversity, management must not only believe in the value of crisis planning, they need to understand the components of effective. 
Table 6: Practices that Integrate Social Media in Crisis Communication

University has Implemented Policies to Address Potential Vulnerabilities

Universities have used Social Media as a Tool for Crisis

Monitoring

Employees have been prepared in advance to respond to crisis

Staff understand the Response-ability of Social Media

There is a Framework for Response by social media

There is a Social Media Crisis Toolkit

$\begin{array}{cccccc}\mathbf{A} & \mathbf{O} & \mathbf{S} & \mathbf{R} & \mathbf{N} & \text { Mean } \\ 08 & 44 & 22 & 04 & 02 & 4.30 \\ 10.0 \% & 55.0 \% & 27.5 \% & 5.0 \% & 2.5 \% & \\ 24 & 22 & 12 & 20 & 02 & 3.08 \\ 30.0 \% & 27.5 \% & 15.0 \% & 25.0 \% & 2.5 \% & \\ 04 & 18 & 52 & 04 & 02 & 3.03 \\ 5.0 \% & 22.5 \% & 65.0 \% & 5.0 \% & 2.5 \% & \\ 08 & 44 & 22 & 04 & 02 & 3.85 \\ 10.0 \% & 55.0 \% & 27.5 \% & 5.0 \% & 2.5 \% & \\ 20 & 40 & 06 & 10 & 04 & 3.81 \\ 25.0 \% & 50.0 \% & 7.5 \% & 12.5 \% & 5.0 \% & \\ 08 & 42 & 28 & 20 & 02 & 3.18 \\ 10.0 \% & 52.5 \% & 35.0 \% & 25.0 \% & 2.5 \% & \\ & & & & & \end{array}$

Source: Field Data (2016)

Data in Table 6, shows that respondents stated that the university has implemented policies to address potential vulnerabilities with a mean of 4.30 was a practice that integrated social media into crisis communication. Staff understand the response ability of social media were practice that integrated social media into crisis communication this was shown by a mean of 3.85. Respondents stated that there is a framework for response by social media with a mean of 3.81 was a practice that integrated social media into crisis communication. Employees have been prepared in advance to respond to crisis indicated by a mean score of 3.03 was the practice that integrated social media into crisis communication. Therefore, most of the respondents feel that university implementing policies to address potential vulnerabilities is the best practice that integrated social media into crisis communication.

Impact social media usage in crisis communication amongst university campuses

Respondents were asked to rate the effects of the use of social media as an instrument for crisis communication amongst university campuses using the scale below; $\mathrm{SA}=$ Strongly Agree; $\mathrm{A}=$ Agree; $\mathrm{U}=$ Undecided; $\mathrm{D}=$ Disagree; $\mathrm{SD}=$ Strongly Disagree

Table 7: Impact of the use of social media as an instrument for crisis communication

\begin{tabular}{|c|c|c|c|c|c|c|}
\hline & SA & A & $\mathbf{U}$ & D & SD & \\
\hline \multirow[t]{2}{*}{ My organization uses social media to respond to crisis } & 18 & 32 & 38 & 16 & & \multirow[t]{2}{*}{4.06} \\
\hline & & & $42.5^{\circ}$ & $12.5 \%$ & $5.0 \%$ & \\
\hline \multirow{2}{*}{$\begin{array}{l}\text { Social media during a crisis has strengthened my } \\
\text { organization's relationship with stakeholders }\end{array}$} & 22 & 22 & 34 & 12 & 10 & \multirow[t]{2}{*}{3.63} \\
\hline & 22.5 & 22.5 & $3 / .2$ & 10. & $7.5 \%$ & \\
\hline \multirow{2}{*}{$\begin{array}{l}\text { Using social media during a crisis helped save time } \\
\text { when responding to the crisis }\end{array}$} & 10 & 18 & 24 & 42 & 06 & \multirow[t]{2}{*}{3.44} \\
\hline & $7.5 \%$ & $17.5 \%$ & $25.0 \%$ & 47.5 & $2.5 \%$ & \\
\hline \multirow[t]{2}{*}{ Using social media during a crisis helped save money } & 16 & & 20 & 28 & 06 & \multirow[t]{2}{*}{3.18} \\
\hline & $7.5 \%$ & $32.5 \%$ & $20.0^{\circ}$ & $30.0^{\circ}$ & $2.5 \%$ & \\
\hline \multirow{2}{*}{$\begin{array}{l}\text { Social media improved my organization's image during a } \\
\text { crisis }\end{array}$} & 24 & 44 & 10 & 14 & 08 & \multirow[t]{2}{*}{3.35} \\
\hline & $25.0 \%$ & $50.0 \%$ & $7.5 \%$ & $12.5 \%$ & $5.00 \%$ & \\
\hline \multirow{2}{*}{$\begin{array}{l}\text { Social media helped to encourage two-way } \\
\text { communication during a crisis }\end{array}$} & 12 & 24 & 34 & 10 & 00 & \multirow[t]{2}{*}{3.57} \\
\hline & $15.0 \%$ & $30.0 \%$ & $42.5^{\circ}$ & $12.5 \%$ & $0.0 \%$ & \\
\hline \multirow{2}{*}{$\begin{array}{l}\text { Social media has helped inform our stakeholders quickly } \\
\text { during a crisis }\end{array}$} & 18 & 18 & 30 & 08 & 06 & \multirow[t]{2}{*}{4.22} \\
\hline & $22.5^{\circ}$ & $22.5^{\circ}$ & $37.5^{\circ}$ & $10.0^{\circ}$ & $7.5 \%$ & \\
\hline \multirow{2}{*}{$\begin{array}{l}\text { Social media helped reach a wide range of stakeholders } \\
\text { during a crisis }\end{array}$} & 06 & 14 & 20 & 38 & 02 & \multirow[t]{2}{*}{3.63} \\
\hline & $7.5 \%$ & $17.5 \%$ & $25.0^{\circ}$ & $47.5 \%$ & $2.5 \%$ & \\
\hline \multirow{2}{*}{$\begin{array}{l}\text { Social media helped improve our stakeholder's } \\
\text { perception of the organization during a crisis }\end{array}$} & 12 & 26 & 16 & 24 & 02 & \multirow[t]{2}{*}{4.18} \\
\hline & $7.5 \%$ & $32.5 \%$ & $20.0 \%$ & $30.0 \%$ & $2.5 \%$ & \\
\hline \multirow{2}{*}{$\begin{array}{l}\text { My organization plans to use social media in our next } \\
\text { crisis }\end{array}$} & 20 & 40 & 06 & 10 & 04 & \multirow[t]{2}{*}{3.95} \\
\hline & $25.0 \%$ & $50.0 \%$ & $7.5 \%$ & $12.5 \%$ & $5.00 \%$ & \\
\hline
\end{tabular}

\section{Source: Field Data (2016)}

Information in table 7 , indicates that the respondents were of the opinion that social media has helped inform our stakeholders quickly during a crisis with a mean of 4.22 was an effect of the use of social media as an instrument for crisis communication. Respondents affirmed that Social media helped improve our stakeholder's perception of the organization during a crisis by a mean of 4.18 was an effect of the use of social media as an instrument for crisis communication. Respondents stated that social media helped reach a wide range of stakeholders during a crisis with a mean of 3.63 this was an effect of the use of social media as an instrument for crisis communication. Social media improved my organization's image during a crisis indicated by a mean score 
of 3.35 was the least effect of the use of social media as an instrument for crisis communication. Therefore, most of the respondents feel that Social media has helped inform our stakeholders quickly during a crisis was an effect of the use of social media as an instrument for crisis communication. Liu (2010) argues that during a crisis period, people seek in-depth crisis information in contrast with Stephens \& Malone (2009) who posts that people usually tend to depend on word of mouth by using social media instead of searching for information directly from a corporate website or blogs. They argue that this is because blogs just tend to allow people to engage in knowledge sharing, reflection and the exchange of views, which normally encourages the public for the purpose of readership and builds trust after a crisis (Valentini \& Romenti, 2011). Thus, during a crisis, people tend to seek and use various types of social media to gather as much additional information as possible regarding the risks and responsibilities of the crisis (Valentini \& Romenti, 2011). In addition, Facebook has more than one billion users worldwide (Hysenlika, 2012), which represent the most popular social media site. Hysenlika (2012) claimed that Facebook allows communicators (individual or organisation) to deliver messages based on their needs quickly and effectively during a crisis period

\subsection{Conclusions}

The use of the social media cannot be ignored in crisis communication. Social media creates meaning, provides sufficient information and limits harm during crisis communication. When up to date information is distributed via the social media, the public stays informed about the status of the incident. This also means that authorities can inform citizens about what they are exactly doing. The analysis shows that the use of the social media in crisis communication brings positive as well as negative effects with it. Positive effects are that the social media make it possible to adapt the specific crisis communication strategy to the specific questions and needs of the public. This can on the one hand be done by making use of an environmental analysis and on the other hand by making use of the social media to interact with the public. By making the crisis communication transparent in this manner, the performed crisis communication will eventually most likely also be evaluated more positive and with this the democratic legitimacy of the crisis communication can be increased.

But there is also a downside on this perspective. This is the case when the performed crisis communication does not take into account the questions and needs of the public, where public's opinion about the crisis communication will most likely decrease. This study has demonstrated the value of use of social media such as whatsapp, Twitter among others as tools for communication with the wider population during periods of crisis. Where social media mark a major advance on traditional modes of communication is in the two-way, interactive nature of the medium. This enables information to be received, and messages to be communicated, throughout the community, and provides authorities with on-the-ground intelligence that can be shared quickly in rapidly changing situations.

Data indicated that whatsapp is the the most used social media by the university campuses in Kisii County. As a tool for mobile devices, WhatsApp has several capabilities such as portability, ability to share several message formats such as graphics and geographical location, ability to send voice notes and ability to broadcast one message to many recipients. This makes it attractive to the majority of the users. Yeboah and Ewur (2014) note that, "this application is highly addictive and can create a great impact on regular users, and apart from that it can leave a trace that becomes difficult to control and cure". The expectation that one must respond to WhatsApp messages immediately, is also an influencer of the usage, hence most users tend to ensure that they are available and online for others to reach them. WhatsApp capabilities attract the technology division staff to its use, in that they are able to access information regardless of their geographical location, especially with the numerous travel and site visits by the engineers.

\section{REFERENCES}

Adika, O. (2014, March 5). news. Retrieved September 6, 2020, from techweez: http://www.techweez.com/2014/03/05/49-of-kenyans-mobile-users-on-whatsapp/

Aggarwal, Y.P. (2008). Statistics of Education. (2nd Ed.) Delhi: Sterling

Anderson, J. Q., Rainie, L., 2010. The Future of Social Relations. Pew Research Center's Internet \& American Life Project, 2.

Anderson, K. E., \& Anderson, K. (2016). Getting acquainted with social networks and apps: WhatsApp-ening with mobile instant messaging? Library Hi Tech News, 33(6), 11-15.

Arthur, C. (2011, October 13), "BlackBerry services restored but could be subject to more disruption", University of New York Press.

Auer, M. R. (2011). "The policy sciences of social media", The Policy Studies Journal, Vol. 39, No. 4, pp. 707736.

Austen, I. (2011, October 11), "Blackberry points to equipment failure", The New York Times, retrieved from http://www.nytimes.com.

Axel S. (2014) Strategic Leadership of the Digital Media Transformation. Stanford graduate school press. 
Bafna, S. (2011). "Balance reduction - Vodafone India's favourite foul play", Telecom Talk, retreived from http://telecomtalk.info/balance-reduction-vodafone-indias-favourite-foul-play/83582/.

Benoit, W. L. (1995), "Accounts, excuses, and apologies: a theory of image restoration strategies", State University of New York Press.

Benoit, W. L. (1997), "Image repair discourse and crisis communication”, Public Relations Review, Vol. 23, Iss: 2, pp. 177-186.

Cho, S. E., Park, H. W., 2013. Social Media Use during Japan's 2011 Earthquake: How Twitter Transforms the Locus of Crisis Communication. Media International Australia Incorporating Culture \& Policy, (149), P. 28.

Cho, S. H. \& Gower, K. K. (2006), "Framing effect on the public's response to crisis: human interest frame and crisis type influencing responsibility and blame", Public Relations Review, Vol. 32, Iss: 4, p. 420-422.

Church , K., \& de Oliveira, R. (2013). What's up with whatsapp?: comparing mobile instant messaging behaviors with traditional SMS. Proceedings of the 15th international conference on Human-computer interaction with mobile devices and services. (pp. 352-361). ACM.

Coomb, W. T., 2012. Ongoing Crisis Communication: Planning, Managing, and Responding. Thousand Oaks, Calif: SAGE

Coombs, T. W. \& Holladay, S. J. (2006), "Unpacking the halo effect: reputation and crisis management", Journal of Communication Management, Vol. 10, Iss: 2, pp.123 - 137.

Coombs, T. W. \& Holladay, S. J. (2009), "Further explorations of post-crisis communication: effects of media and response strategies on perceptions and intentions.", Public Relations Review, Vol. 35, pp. 1-6.

Coombs, T. W. \& Holladay, S. J. (2010), “The handbook of crisis communication”, Wiley-Blackwell, Malden, MA.

Coombs, T. W. (1999), “Ongoing crisis communication: planning, managing, and responding”, Thousand Oak, SAGE Publications.

Coombs, T. W. (2007), "Protecting organization reputations during a crisis: the development and application of situational crisis communication theory, Corporate Reputation Review, Vol. 10, No. 3, pp. 163-176.

Egelhoff, W. G. \& Sen, F. (1992), “An information-processing model of crisis management", Management Communication Quarterly, Vol. 5, pp. 443-484.

Eid, M., Fyfe, T., 2009. Globalisation and Crisis Communication. Journal of International Communication, 15(2).

Energex, n.d.. Social media terms of use. https:/www.energex.com.au/residential-and-business/contactenergex/follow-us/social-media-policy

Fediuk, T.A., Coombs, W.T. \& Botero, I.C. (2010), "Exploring crisis from a receiver perspective: understanding stakeholder reactions during crisis events", in Coombs, W.T. and Holladay, S.J., Handbook of Crisis Communication, Wiley-Blackwell, Malden, MA, pp. 635-56.

Gassée, J. (2012), “RIM's future: dead, alive or reborn?”, The Guardian, retrieved from University of New York Press.

Goldfine, E., 2011. Best Practices: The Use of Social Media throughout Emergency \& Disaster Relief (Doctoral Dissertation). https://www.american.edu/soc/communication/upload/erica-goldfine.pdf

Hysenlika, V., 2012. Communicating During an Organizational Crisis: Using Facebook as a Relationship Management Tool (Doctoral Dissertation, University Of South Florida).

Jin, Y., Liu, B. F. \& Austin, L. L. (2011), "Examining the role of social media in effective crisis management: the effects of crisis origin, information form, and source on publics' crisis responses", Communication Research, pp. 1-21.

Jin, Y., Liu, B. F., Austin, L. L., (2014). Examining the Role of Social Media in Effective Crisis Management: The Effects of Crisis Origin, Information Form, and Source on Publics' Crisis Responses. Communication Research, 41(1), 74-94.

Jin, Y., Liu, B.F., (2010). The Blog-Mediated Crisis Communication Model: Recommendations for Responding To Influential External Blogs. Journal of Public Relations Research, 22(4), Pp. 429-455.

Kaplan, A. M. \& Haenlein, M. (2010), "Users of the world, unite! The challenges and opportunities of social media", Business Horizons, Vol. 1, pp. 59-68.

Lesenciuc, A., Nagy, A.D., (2008). Role of Communication in Crisis Management. http://search.proquest.com/docview/1127282857?accountid=13380

Lin, Y. (2007). "Testing the effects of apology and compassion response in product-harm crises in situational crisis communication theory", Michigan State University.

Liu, B. F., (2010). Distinguishing How Elite Newspapers And A-List Blogs Cover Crises: Insights For Managing Crises On And Offline. Public Relations Review, 36(1), 28-34.

Liu, B. F., Austin, L. \& Jin, Y. (2011), "How publics respond to crisis communication strategies: the interplay of information form and source", Public Relations Review, Vol. 37, pp. 345- 353.

Macnamara, J. (2010), "Public relations and the social: how practitioners are using, or abusing, social media", Asia Pacific Public Relations Journal, Vol. 11, pp. 21-39. 
Manovich, L. (2000), "What is new media?" In "The language of new media", Cambridge, Mass: MIT Press.

McCorkindale, T.C. (2009), "Can you see the writing on my wall? A content analysis of the Fortune 50's Facebook social networking sites", Paper presented to the 12th Annual International Public Relations Research Conference, Coral.

Meyrowitz, J. (1993). "Images of media: hidden ferment - and harmony - in the field", Journal of Communication, Vol. 43., Iss: 3, pp. 55-66.

Michelle G. Hough (2011) Crisis Planning: Increasing Effectiveness, Decreasing Discomfort. Journal of Business \& Economics Research (JBER) 3(4).

Mitchell, R. K., Agle, B. R. \& Wood, D. J. (2007), “Toward a theory of stakeholder identification and salience: defining the principle of who and what really counts, The Academy of Management Review, Vol. 22, No. 4, pp. 853-886.

Modéus, G., Paulsson, R., Olsson, H., (2012). Crisis Management in Social Media. (Unpublished Bachelor Thesis), Linnæus University, Sweden.

Muralidharan, S., Dillistone, K., Shin, J. H., (2011). The Gulf Coast Oil Spill: Extending the Theory of Image Restoration Discourse to the Realm of Social Media and Beyond Petroleum. Public Relations Review, 37(3), 226-232.

Orodho, A. \& Kombo, D (2002). Research Methods, Nairobi, Kenyatta University, Institute of Open Learning.

Pace, K. M., Fediuk, T. A. \& Botero, I. C. (2010). "The acceptance of responsibility and expressions of regret in organizational apologies after a transgression", Corporate Communications: An International Journal, Vol. 15, Iss: 4, pp. 410-427.

Pang, A., Hassan, N. B. B. A., Chong, A. C. Y., (2014). Negotiating Crisis in the Social Media Environment: Evolution of Crises Online, Gaining Credibility Offline. Corporate Communications: An International Journal, 19(1), 7-7.

Pennington-Gray, L., Donohoe, H., Kiousis, S., (2013). Using Social Media in Times of Crisis. Journal of Travel \& Tourism Marketing, 30(1-2), 126-143.

Pondres (2011). The role of social media in crisis communication from a democratic perspective. university of twente.

Rainie, L., 2010. The Future of Social Relations. Pew Research Center's Internet \& American Life Project, 2.

Rosenwasser, D. \& Stephen, J. (2012), "Writing analytically", Chapter $18,6^{\text {th }}$ Ed., Wadsworth: Boston.

Safaricom (2006). Safaricom communication policy. Communication policy. Safaricom Limited.

Safaricom (2006). Safaricom communication policy. Communication policy. Safaricom Limited.

Safranek, R., (2012) The Emerging Role of Social Media in Political and Regime Change. Discovery Guides.

Schroeder, A., Pennington-Gray, L., (2014). The Role of Social Media in International Tourist's Decision

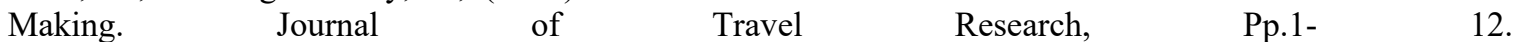
http://jtr.sagepub.com/content/early/2014/03/24/0047287514528284.full.pdf+html Schroeder,

Schultz, F., Utz, S., Goritz, A., (2011). Is The Medium The Message? Perceptions of and Reactions to Crisis Communication via Twitter, Blogs and 658 Nor Emmy Shuhada Derani and Prashalini Naidu / Procedia Economics and Finance 35 (2016) 650 - 658 Traditional Media. Public Relations Review, 37(1), 20-27.

Shirky, C. (2011). The political power of social media: Technology, the public sphere, and political change. Foreign Affairs, 90(1), 28-41

Solis, B. \& Breakenridge, D. (2009), "Putting the public back in public relations", Upper Saddle River, NJ: Pearson Education, pp. 314.

Stephens, K. K., Malone, P. C. \& Bailey, C. M. (2005), "Communicating with stakeholders during a crisis: evaluating message strategies", Journal of Business Communication, Vol. 42, pp. 390.

Stephens, K. K., Malone, P. C., (2009). If The Organizations Won't Give Us Information...: The Use Of Multiple New Media For Crisis Technical Translation And Dialogue. Journal of Public Relations Research, 21(2), 229-239

Sunstein, C. R. (2006). Infotopia, New York: Oxford University Press.

Valentini, C., Romenti, S., (2011). Blogging about Crises. Journal of Communication Management, 15(4), 298313.

http://search.proquest.com.ezp01.library.qut.edu.au/docview/904961685/fulltextPDF?accountid=13380

Veil, S. R., Buehner, T., Palenchar, M. J., (2011). Literature Review: Incorporating Social Media in Risk and Crisis Communication. Journal of Contingencies and Crisis Management, 19(2), 110-122.

Walaski, P. F., (2011). Risk and Crisis Communications: Methods and Messages. John Wiley \& Sons.

Walaski, P., (2013). Social Media. Professional Safety, 58(4), $40-49$. http://search.proquest.com/docview/1331594111?accountid=13380

Wariara, K.N.M (2017). Use of whatsapp as an organizational communication platform: a kenya's safaricom technology division. Thesis submitted to United States International University Africa 
Wendling, C., J. Radisch, S. Jacobzone, (2013). The Use of Social Media in Risk and Crisis Communication, OECD Working Papers On Public Governance, No. 25, OECD Publishing.

WhatsApp. (2016). WhatsApp. Retrieved Oct 01, 2020, from WhatsApp: http://blog.whatsapp.com/

White, B., King, I., Sang, P., (2011). Social Media Tools and Platforms in Learning Environments. Springer Science \& Business Media.

White, C. M., (2012). Social Media, Crisis Communication, and Emergency Management: Leveraging Web 2.0 Technologies. Boca Raton, FL: CRC Press.

Wigley, S. \& Fontenot, M. (2010), "Crisis managers losing control of the message: A pilot study of the Virginia Tech shooting”, Public Relations Review, Vol. 36, pp. 187-189.

Wigley, S. \& Zhang, W. (2011), “A study of PR practitioners' use of social media in crisis planning”, Public Relations Journal, Vol. 5, No. 3., pp. 1-16.

Wolf, D.D., Mejri, M., (2013). Crisis Communication Failures: The BP Case Study. International Journal of Advances in Management and Economics, 2(2), 48-56.

Xiang, Z., \& Gretzel, U. (2010). Role of Social Media in Online Travel Information Search. Tourism Management, 31, 179-188.

Yates, D., Paquette, S., (2011). Emergency Knowledge Management and Social Media Technologies: A Case Study of the 2010 Haitian Earthquake. International Journal of Information Management, 31(1), 6-13. http://www.sciencedirect.com.ezp01.library.qut.edu.au/science/article/pii/

Yeboah, J., \& Ewur, G. D. (2014). The impact of Whatsapp messenger usage on students' performance in tertiary institutions in Ghana. Journal of Education and Practice, 5(6), 157-164. Retrieved from http://www.iiste.org/Journals/index.php/JEP/article/view/11241/11555

Zaremba, A. J., (2010). Crisis Communication: Theory and Practice. In Barclay, L.A. (2010), Business Communication Quarterly (P.473).Armonk, NY: M. E. Sharp. 